\title{
Metathesis in Oleochemistry
}

\author{
Johannes C. Mol ${ }^{a}$, and Regina Buffon ${ }^{b}$ \\ ${ }^{a}$ J.H. van 't Hoff Research Institute, Universiteit van Amsterdam, Nieuwe Achtergracht \\ 166, 1018 WV Amsterdam, The Netherlands; \\ ${ }^{b}$ Instituto de Química, Universidade Estadual de Campinas, C.P. 6154, 13083-970 \\ Campinas - SP, Brazil
}

Received: June 6, 1997

\begin{abstract}
Metátese é uma reação atraente para a conversão de óleos e gorduras em produtos químicos úteis. Assim, a metátese de ésteres de ácidos graxos insaturados (constituintes básicos de óleos e gorduras) é uma rota conveniente para a síntese de diésteres insaturados, que podem ser usados como intermediários na produção de polímeros e na química fina. A metátese cruzada com olefinas simples permite alterar o comprimento da cadeia carbonada de ácidos graxos e de seus derivados; a metátese cruzada com eteno (etenólise) fornece compostos contendo ligações duplas terminais, que possuem uma extensa gama de aplicações. A etenólise de óleos graxos (triglicerídeos) permite a transformação de triglicerídeos de ácidos graxos de longas cadeias carbonadas em óleos graxos de menor massa molecular. Diversos sistemas catalíticos - homogêneos ou heterogêneos -, altamente seletivos, se mostraram capazes de efetuar a metátese de ésteres insaturados. Catalisadores heterogêneos à base de rênio ou de molibdênio têm atraído muita atenção. Considerando os procedimentos de ativação e de regeneração do catalisador, os sistemas catalíticos à base de rênio são preferidos.
\end{abstract}

Metathesis is an attractive reaction for the conversion of oleochemical feedstocks into useful chemical products. Thus, metathesis of unsaturated fatty acid esters (the oleochemical raw materials) provides a convenient route to unsaturated diesters which can be used as intermediates for the production of polymers and specialty chemicals. Cross-metathesis with olefins is a means to change the chain length of fatty acids and derivatives; cross-metathesis with ethene (ethenolysis) gives compounds with terminal double bonds, having a broad range of applications. Ethenolysis of fatty oils or triglycerides allows the transformation of long-chain fatty acid triglycerides into fatty oils of lower molecular weight. Several highly selective catalyst systems - homogeneous as well as heterogeneous - have proven to be successful for the metathesis of unsaturated esters. Especially modified heterogeneous rhenium- and molybdenum-based catalysts have attracted much attention. Considering catalyst activation and regeneration procedures, rhenium-based catalysts are to be preferred.

Keywords: metathesis, catalysts, oleochemicals, esters

\section{Introduction}

\section{Fats and oils}

In the next century the availability of fossil organic feedstocks - both as energy sources and for the production of organic chemical raw materials - will gradually decrease. Hence it is important to look for alternatives. These can be found in renewable resources both for energy purposes as well as for raw materials for the chemical industry. In the latter case, much attention has already been given to the use of natural fats and oils of vegetable and animal origin in the oleochemical industry. Oleochemicals are not only produced from renewable resources, but they also have the advantage of a good biodegradability and no net $\mathrm{CO}_{2}$ production.

Fats and oils (composed predominantly of glyceryl esters of fatty acids) are important sources both for nutrition 
and as raw materials for the oleochemical industry. About $15 \%$ of the world production of fats and oils (81 million t/a in 1990, 105 million t/a expected in 2000) is used in the oleochemical industry as starting materials for a wide range of chemical products ${ }^{1}$. The most important group from the point of view of cost-effectiveness is that of the long-chain vegetable oils, such as soybean oil, sunflower oil and new rapeseed oil (all consisting mainly of unsaturated $\mathrm{C}_{18}$ fatty acid chains) and palm oil (containing both $\mathrm{C}_{16}$ and $\mathrm{C}_{18}$ chains). The oleochemical industry prefers a high content of oleic acid (mono-unsaturated $\mathrm{C}_{18}$ fatty acid) because this is an important starting material for many consecutive chemical reactions. Short- and medium-chain fatty oils, such as palm-kernel oil and coconut oil, consist mainly of lauric $\left(\mathrm{C}_{12}\right)$ and myristic $\left(\mathrm{C}_{14}\right)$ acid and are important sources for the production of detergents, soaps, emulsifiers, etc. Animal fats, such as tallow (containing $40-45 \%$ oleic acid), are also in demand as raw material, mainly because of their low price. Some other vegetable oils are the source of oleochemicals on a smaller scale. An example is castor oil, consisting mainly (85-95\%) of ricinoleic acid, which has a wide range of industrial uses.

The feedstocks for vegetable oils and fats come from different parts of the world. Soybeans are produced chiefly in the USA, Brazil, China and Argentina, rapeseed in China, Europe, Canada and India, and sunflowers in East \& South Europe and Central \& South America. Coconut and palm kernel oil come from Southeast Asian Countries.

Fatty acid esters are generally obtained by transesterification of natural oils and fats with a lower alcohol, e.g. methanol. Although more than $95 \%$ of all chemical reactions (e.g. conversion into fatty alcohols and fatty amines) of fatty acid esters (or acids) are carried out at the carboxy function, transformation of unsaturated fatty acid esters by reactions of the carbon-carbon double bond, such as hydrogenation, epoxidation, ozonolysis, hydroformylation and dimerization, are becoming increasingly of industrial importance. Metathesis is another reaction of the carbon-carbon double bond.

\section{Metathesis}

Olefin metathesis is a catalytic exchange reaction between two alkene molecules during which two alkylidene groups are interchanged. For normal olefins this can be represented by reaction (1).

\section{$2 \mathrm{R}-\mathrm{CH}=\mathrm{CH}-\mathrm{R}^{\prime} \rightleftharpoons \mathrm{R}-\mathrm{CH}=\mathrm{CH}-\mathrm{R}+$$$
\mathrm{R}^{\prime}-\mathrm{CH}=\mathrm{CH}-\mathrm{R} \text { ' }
$$

A simple example is the metathesis of propene $(\mathrm{R}=\mathrm{H}$; $\mathrm{R}^{\prime}=\mathrm{CH}_{3}$ ) into ethene and but-2-ene. The forward reaction is often called self-metathesis, while the reverse reaction, i.e. a reaction between two different alkene molecules, is called cross-metathesis. In fact, many olefinic substrates can un- dergo metathesis in the presence of a suitable catalyst, resulting in a wide variety of possible products. These substrates include acyclic alkenes, dienes, polyenes, cyclic alkenes, and also functionally substituted alkenes, such as unsaturated esters, nitriles, halogens etc.

At the moment there are various commercial applications of olefin metathesis: (i) the production of polymerisation-grade propene via cross-metathesis between ethene and but-2-ene; this is, in fact, the reverse process of the first industrial application of the olefin metathesis reaction, viz. the metathesis of propene into high-purity ethene and but-2-ene, called the Phillips Triolefin Process, which was in operation from 1966 till 1972; (ii) the production of neohexene (an important intermediate in the manufacture of synthetic musks) via cross-metathesis of di-isobutene with ethene; (iii) the Shell Higher Olefins Process (SHOP), a large-scale industrial process incorporating olefin metathesis, for converting ethene to detergent-range olefins; (iv) the production of several kinds of polymers produced via the metathesis of cyclic olefins, such as cyclooctene, norbornene, and dicyclopentadiene. A promising synthetic application for the metathesis reaction concerns the metathesis of acyclic olefins containing heteroatom functional groups. This would allow single-step syntheses of various mono- and difunctional derivatives of hydrocarbons with well-defined structures.

Considering the extensive possibilities offered by the metathesis of unsaturated hydrocarbons within chemical synthesis, it is not surprising that much research is being carried out into the development of active and selective catalysts for this reaction. The metathesis reaction can be catalysed by both heterogeneous and homogeneous catalysts. A wide variety of transition metal compounds will catalyse the reaction, the most important ones being based on W, Mo, Re and Ru. Heterogeneous catalysts generally consist of a transition metal oxide, or an organometallic precursor, deposited on a high-surface-area support (an inorganic oxide). Examples are $\mathrm{Re}_{2} \mathrm{O}_{7} / \mathrm{Al}_{2} \mathrm{O}_{3}, \mathrm{MoO}_{3} / \mathrm{SiO}_{2}$, $\mathrm{WO}_{3} / \mathrm{SiO}_{2}$, and $\left(\pi-\mathrm{C}_{4} \mathrm{H}_{7}\right)_{4} \mathrm{~W} / \mathrm{SiO}_{2}$. In particular a supported $\mathrm{Re}_{2} \mathrm{O}_{7}$ catalyst shows pronounced activity and high selectivity even at room temperature; when promoted with $\mathrm{R}_{4} \mathrm{Sn}(\mathrm{R}$ $=\mathrm{Me}, \mathrm{Et}, \mathrm{Bu})$ it becomes also active for the metathesis of unsaturated esters and other functionalized olefins. Homogeneous catalysts mainly consist of (i) a combination of the transition metal compound (usually a chloride, such as $\mathrm{WCl}_{6}, \mathrm{WOCl}_{4}$ and $\mathrm{ReCl}_{5}$ ) and an organometallic compound, e.g. $\mathrm{R}_{4} \mathrm{Sn}\left(\mathrm{R}=\right.$ alkyl) or $\mathrm{EtAlCl}_{2}$, as cocatalyst, or (ii) a well-defined alkylidene (carbene) complex of a transition metal, e.g. $\mathrm{Ru}\left(=\mathrm{CHCH}=\mathrm{CPh}_{2}(\mathrm{Cl})_{2}\left(\mathrm{PCy}_{3}\right)_{2}\right.$. Only a relatively small number of the many metathesis catalyst systems are able to bring about the metathesis of functionalized olefins; these will be discussed in Catalysts section. 
Metathesis is a transalkylidenation reaction and it is generally accepted that the reaction proceeds via the so-called metal-carbene mechanism. The propagation reaction involves a transition-metal carbene as the active species with a vacant co-ordination site at the transition metal. The alkene co-ordinates at this vacant site, and subsequently a metallacyclobutane intermediate is formed. The metallacycle is unstable and cleaves to form a new metal carbene complex and a new alkene, reaction (2). The initial metal carbene can be formed by a reaction between the catalyst and the cocatalyst, if present, or by interaction of the substrate alkene with the transition metal centre. When using an actual metal carbene as catalyst a metal-carbene forming step is, of course, not necessary. A detailed monograph dealing with all aspects of olefin metathesis has recently appeared ${ }^{2}$.

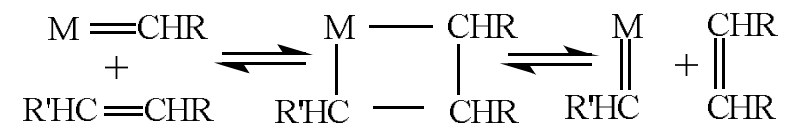

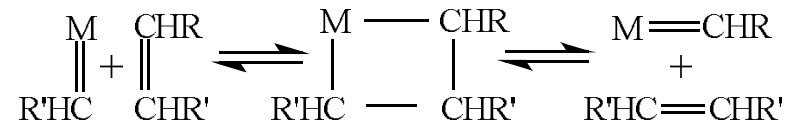

\section{Metathesis of Unsaturated Fatty Acid Esters}

\section{Self-metathesis}

Unsaturated fatty acid esters and fatty oils are very promising and cheap feedstocks for metathesis. For this reason, the metathesis reaction is of interest to the oleochemical industry.

The first successful metathesis conversion in this area was the selective transformation of methyl oleate (methyl cis-octadec-9-enoate), a readily available ester, into equimolar amounts of octadec-9-ene and dimethyl octadec-9-enoate in the presence of a $\mathrm{WCl}_{6} / \mathrm{Me}_{4} \mathrm{Sn}$ catalyst system $^{3}$, reaction (3).

$$
\begin{gathered}
2 \mathrm{Me}\left(\mathrm{CH}_{2}\right)_{7} \mathrm{CH}=\mathrm{CH}\left(\mathrm{CH}_{2}\right)_{7} \mathrm{COOMe} \rightleftharpoons \\
\mathrm{Me}\left(\mathrm{CH}_{2}\right)_{7} \mathrm{CH}=\mathrm{CH}\left(\mathrm{CH}_{2}\right)_{7} \mathrm{Me}+ \\
\mathrm{MeOOC}\left(\mathrm{CH}_{2}\right)_{7} \mathrm{CH}=\mathrm{CH}\left(\mathrm{CH}_{2}\right)_{7} \mathrm{COOMe}
\end{gathered}
$$

Because the free enthalpy change in this type of reaction is virtually zero, the result at equilibrium is a random distribution of the alkylidene groups. Thus, starting with methyl oleate, the equilibrium mixture consists of $50 \mathrm{~mol} \%$ of the starting material and $25 \mathrm{~mol} \%$ of each of the products octadec-9-ene and dimethyl octadec-9-enoate. The cis/trans ratio of the reaction products is also in accordance with thermodynamics. This demonstrates that - in the presence of a suitable catalyst - the metathesis of unsaturated fatty acid esters provides a convenient and highly selective route to unsaturated diesters. Unsaturated diesters can be used for the production of useful chemical products such as macrocyclic compounds. For instance, the diester obtained by metathesis of ethyl oleate has been subjected to a two-step reaction sequence, i.e. a Dieckmann condensation followed by hydrolysis-decarboxylation to give 9-cycloheptadecen-1-one, whose cis form, civetone, is an important base material in the perfume industry ${ }^{4,5}$, reaction (4). Moreover, unsaturated dicarboxylic esters and acids are interesting starting materials for the manufacture of polyesters and polyamides ${ }^{6}$.On the other hand, the product octadec-9-ene can be dimerized and hydrogenated to 10,11-dioctyleicosane, a lube-oil range hydrocarbon intermediate $^{7}$.

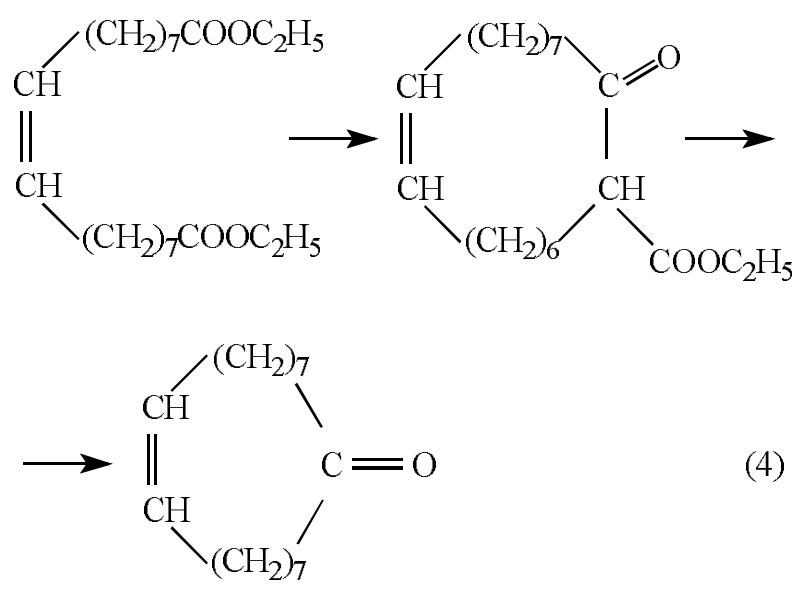

Many other unsaturated fatty acid methyl esters of the general formula $\mathrm{Me}\left(\mathrm{CH}_{2}\right)_{n} \mathrm{CH}=\mathrm{CH}\left(\mathrm{CH}_{2}\right)_{m} \mathrm{COOMe}$ have been shown to undergo metathesis, such as methyl palmitoleate $(n=5, m=7)$, methyl erucate $(n=7, m=11)$ and methyl petroselenate $(n=10, m=4)$. Another example is methyl undec-10-enoate, which can be obtained from castor oil via pyrolysis cleavage of the ricinoleic acid. This reaction proceeds to completion when the by-product ethene is continuously removed during the reaction, reaction (5). It should be noted that olefins with an $\mathrm{OH}$-containing functional group, such as $\mathrm{COOH}$ and $\mathrm{CHO}$, deactivate most catalysts which are active for the metathesis of esters ${ }^{8}$.

\section{$2 \mathrm{CH}_{2}=\mathrm{CH}\left(\mathrm{CH}_{2}\right)_{8} \mathrm{COOMe} \rightleftharpoons$}

$$
\mathrm{MeOOC}\left(\mathrm{CH}_{2}\right)_{8} \mathrm{CH}=\mathrm{CH}\left(\mathrm{CH}_{2}\right)_{8} \mathrm{COOMe}+\mathrm{CH}_{2}=\mathrm{CH}_{2}
$$

For the metathesis of methyl oleate a very pure substrate is required. In an alternative process for the synthesis of civetone, methyl oleate is first converted to the doubly-unsaturated ketone pentatriaconta-9,26-dien-18-one, oleon (1), which can be separated in pure form from the reaction mixture. Oleon is then conver- 
ted into 9-cycloheptadecen-1-one (2) via an intramolecular metathesis reaction (see Scheme 1), at room temperature in the presence of a $\operatorname{Re}_{2} \mathrm{O}_{7}$ catalyst supported on $\mathrm{SiO}_{2}-\mathrm{Al}_{2} \mathrm{O}_{3}$ and promoted with $\mathrm{Bu}_{4} \mathrm{Sn}$. To reduce the possibility of intermolecular metathesis between two oleon molecules it is necessary to carry out the reaction under high dilution conditions ${ }^{9}$.

Metathesis of polyunsaturated fatty acid esters, e.g. methyl linoleate and methyl linolenate, leads to a variety of reaction products, including polyenes, monoesters, diesters and cyclopolyenes ${ }^{10}$.

\section{Cross-metathesis}

Cross-metathesis of unsaturated fatty acid esters with a normal alkene is an elegant way of synthesising homologues of these esters, and greatly extends the versatility of the metathesis reaction in the field of oleochemistry. From most industrial vegetable oil crops fatty acid esters are obtained with a predominant chain length of 18 carbon atoms. Shortening these esters to medium-chain fatty acid esters $\left(\mathrm{C}_{10}-\mathrm{C}_{14}\right)$ is possible via cross-metathesis with lower olefins, see e.g. reaction $(6)^{11-13}$.

\section{$\mathrm{Me}\left(\mathrm{CH}_{2}\right)_{7} \mathrm{CH}=\mathrm{CH}\left(\mathrm{CH}_{2}\right)_{7} \mathrm{COOMe}$$$
+\mathrm{EtCH}=\mathrm{CHEt} \rightleftharpoons \mathrm{EtCH}=\mathrm{CH}\left(\mathrm{CH}_{2}\right)_{7} \mathrm{COOMe}+
$$$$
\mathrm{Me}\left(\mathrm{CH}_{2}\right)_{7} \mathrm{CH}=\mathrm{CHEt}
$$

A large excess of the normal alkene can force the reaction to the product side. Fatty acid derivatives of medium chain length - especially $\mathrm{C}_{12}$ - are in high demand for the industrial production of surfactants. With regard to their chain length these esters are quite similar to those of the fatty acids derived from palm kernel oil and coconut oil. The by-product alkenes, with the double bond near the end of the chain, can be used for example for the production of $\mathrm{C}_{12}-\mathrm{C}_{14}$ alcohols by hydroformylation.

On the other hand, instead of shortening the carbon chain of unsaturated esters, it is possible to lengthen it, as illustra-

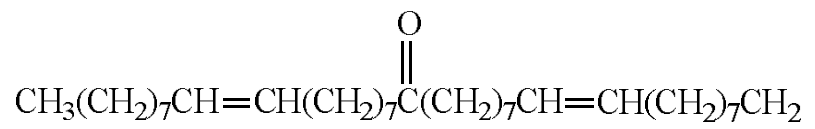

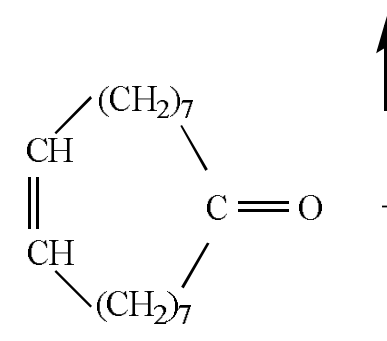

(2)
(1)<smiles>CCCCCC(CC)CCC</smiles>

(3)
Scheme 1. Metathesis of oleon. ted for the cross-metathesis between methyl undec-10-enoate and hex-3-ene in Eq. 7.

$$
\begin{array}{r}
\mathrm{CH}_{2}=\mathrm{CH}\left(\mathrm{CH}_{2}\right)_{8} \mathrm{COOMe}+\mathrm{EtCH}=\mathrm{CHEt} \\
\mathrm{EtCH}=\mathrm{CH}\left(\mathrm{CH}_{2}\right)_{8} \mathrm{COOMe}+\mathrm{CH}_{2}=\mathrm{CHEt}
\end{array}
$$

From a synthetic point of view, cross-metathesis reactions are very promising in opening new routes for the synthesis of derivatives that often can hardly be obtained by other means. An example is the is the synthesis of 1-triacontanol, $\mathrm{CH}_{3}\left(\mathrm{CH}_{2}\right)_{28} \mathrm{CH}_{2} \mathrm{OH}$, a plant growth stimulant, in a relatively simple two-step process by cross-metathesis between methyl erucate and octadec-1-ene in the presence of a $\mathrm{WCl}_{6} / \mathrm{Me}_{4} \mathrm{Sn}$ catalyst, reaction (8), followed by hydrogenation of the ester thus obtained ${ }^{14}$.

$$
\begin{aligned}
\mathrm{Me}\left(\mathrm{CH}_{2}\right)_{7} \mathrm{CH}= & \mathrm{CH}\left(\mathrm{CH}_{2}\right)_{11} \mathrm{COOMe}+ \\
& \mathrm{CH}_{2}=\mathrm{CH}\left(\mathrm{CH}_{2}\right)_{15} \mathrm{Me} \rightleftharpoons \\
& \mathrm{Me}\left(\mathrm{CH}_{2}\right)_{15} \mathrm{CH}=\mathrm{CH}\left(\mathrm{CH}_{2}\right)_{11} \mathrm{COOMe}+ \\
& \mathrm{CH}_{2}=\mathrm{CH}\left(\mathrm{CH}_{2}\right)_{7} \mathrm{Me}
\end{aligned}
$$

Another example of organic synthesis via cross-metathesis is the synthesis of biologically active unsaturated compounds such as insect pheromones. Use of such pheromones offers an effective and selective pest control method. Thus, cross-metathesis of ethyl oleate with dec-5-ene results in a cis-trans mixture of ethyl tetradec-9-enoate, a pheromone precursor ${ }^{15}$. Ethyl tetradec-9-enoate is also obtained by cross-metathesis of mixtures of unsaturated $\mathrm{C}_{18}$ ethyl esters (oleic, linoleic, linolenic) derived from olive, sunflower or linseed oil with excess dec-5-ene ${ }^{16}$. Other examples are summarised elsewhere ${ }^{8,17}$

Cross-metathesis of an unsaturated ester with a cyclic olefin leads to long-chain linear di-unsaturated esters. Thus, 1-triacontanol is also obtained by cross-metathesis between methyl oleate and cyclododecene, reaction (9), followed by hydrogenation of the unsaturated diester product ${ }^{18}$.

$$
\mathrm{Me}\left(\mathrm{CH}_{2}\right)_{7} \mathrm{CH}=\mathrm{CH}\left(\mathrm{CH}_{2}\right)_{7} \mathrm{COOMe}+\stackrel{\left(\mathrm{CH}_{2}\right)_{10}}{{ }^{\square}} \|_{\mathrm{CH}} \rightleftharpoons
$$

$\mathrm{Me}\left(\mathrm{CH}_{2}\right)_{7} \mathrm{CH}=\mathrm{CH}\left(\mathrm{CH}_{2}\right)_{10} \mathrm{CH}=\mathrm{CH}\left(\mathrm{CH}_{2}\right)_{7} \mathrm{COOMe}$

\section{Ethenolysis}

Cross-metathesis of an olefinic compound with ethene is called ethenolysis. Ethenolysis of unsaturated fatty acid esters allows the synthesis of shorter-chain $\omega$-unsaturated esters which have a broad range of applications. An excess of ethene can easily be applied (e.g. by using an ethene pressu- 
res of 30- 50 bar) to suppress self-metathesis of the ester and to force the conversion to completion. The ethenolysis of methyl oleate will lead to methyl dec-9-enoate, together with dec-1-ene ${ }^{19,20}$, reaction (10).

$$
\begin{gathered}
\mathrm{Me}\left(\mathrm{CH}_{2}\right)_{7} \mathrm{CH}=\mathrm{CH}\left(\mathrm{CH}_{2}\right)_{7} \mathrm{COOMe}+\mathrm{CH}_{2}=\mathrm{CH}_{2} \rightleftharpoons \\
\mathrm{Me}\left(\mathrm{CH}_{2}\right)_{7} \mathrm{CH}=\mathrm{CH}_{2}+\mathrm{CH}_{2}=\mathrm{CH}\left(\mathrm{CH}_{2}\right)_{7} \mathrm{COOMe} \quad
\end{gathered}
$$

Methyl dec-9-enoate is the hypothetical source of many polymers and copolymers; it can be converted e.g. into the $\omega$-amino acid, and then used for the production of nylon- 10 . It is an interesting chemical building block for the synthesis of relevant chemical products; after hydrolysis and hydrogenation it yields decanoic acid or decanol, substances used in lubricants and plasticizers. In addition, fragrances can be obtained (such as 9-dec-1-enol and civetone), as can pheromones, prostaglandins etc. ${ }^{8,17}$, which can easily be isolated in pure form. Dec-1-ene, like other alk-1-enes, is an important intermediate in organic syntheses, and has a variety of end uses in polymers, surfactants and lubricants. Ethenolysis of methyl erucate gives another $\omega$-unsaturated ester, methyl tetradec-13-enoate, which could have applications analogous to those of methyl dec-9-enoate.

For efficient production of the diester of methyl oleate a two-step process can be considered ${ }^{21}$. First, methyl oleate undergoes ethenolysis to dec-1-ene and methyl dec-9-enoate; high conversions can be obtained by using a high ethene pressure. After product separation, methyl dec-9-enoate undergoes self-metathesis to ethene and dimethyl octadec-9-enoate. In the latter case the equilibrium can be shifted to the product side by continually removing the volatile ethene. In this way more than $50 \%$ conversion can be obtained in both reaction steps, and there are no big problems in separating the reaction products.

\section{Structure and reactivity of esters in metathesis}

In different studies the relation between the structure of fatty acid esters (and related compounds) and their reactivity in metathesis has been investigated with two types of catalyst systems: $\mathrm{WCl}_{6} / \mathrm{Me}_{4} \mathrm{Sn}$ at $70{ }^{\circ} \mathrm{C}^{11}$ and $\mathrm{Re}_{2} \mathrm{O}_{7} /$ $\mathrm{Al}_{2} \mathrm{O}_{3} / \mathrm{Me}_{4} \mathrm{Sn}$ at $20^{\circ} \mathrm{C}^{12}$. It appeared that the reaction works best if the ester group is not too close to the carbon-carbon double bond. The presence of one or more $\mathrm{CH}_{2}$ groups between the double bond and the ester group is sufficient to ensure that metathesis takes place.

\section{Metathesis of Natural Fats and Oils}

Metathesis of esters of glycerol, i.e. unsaturated fatty oils, proceeds intra- as well as intermolecularly, the latter reaction strongly predominating, reaction (11). Thus, olive oil, which consists mainly of glyceryl trioleate, yields octadec-9-ene and polymeric glycerides (principally dimers and trimers). Metathesis of oils such as olive oil, soybean oil and linseed oil (containing triglycerides of oleic, linoleic and linolenic acid) results in viscous high-molecular-weight oils, so-called stand oils, with outstanding drying properties due to their pronounced unsaturated character ${ }^{17,22}$.

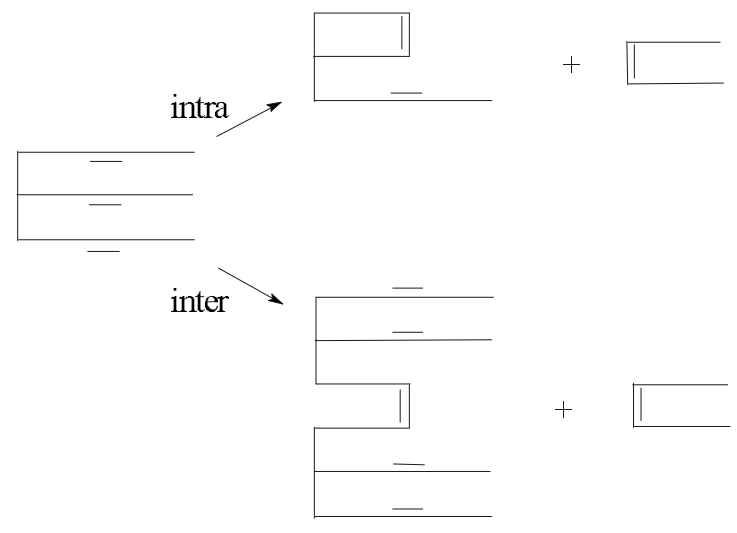

Ethenolysis of distinct fatty oils (olive, soybean, rapeseed, cotton seed) allows, in principle, the transformation of long-chain fatty acid glycerides into glycerides of lower molecular weight, e.g. the production of tricaprin from olive oil (mainly triolein) by ethenolysis and subsequent hydrogenation, reaction (12), and of trimyristin from trierucain along a similar route. As valuable by-products corresponding amounts of terminal olefins are produced. A study of the ethenolysis of triolein (glyceryl trioleate) as model substrate with a supported $\mathrm{Re}_{2} \mathrm{O}_{7}$ catalyst activated with $\mathrm{Bu}_{4} \mathrm{Sn}$ showed that the reaction consists of a sequence of three consecutive ethenolysis reactions, from triolein to tridecenylglycerol, and proceeds with high conversion at room temperature and an ethene pressure of $30 \mathrm{bar}^{23}$.

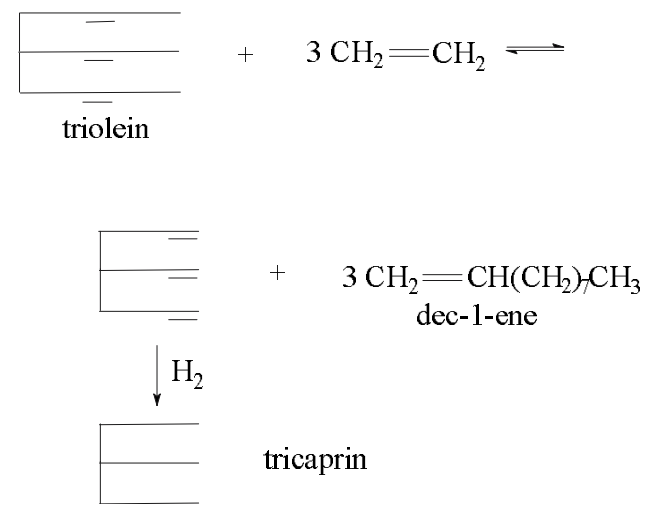

Ethenolysis of polyunsaturated esters, as present e.g. in soybean oil, with an excess of ethene in the presence of the catalyst system $\mathrm{Re}_{2} \mathrm{O}_{7} / \mathrm{Al}_{2} \mathrm{O}_{3} / \mathrm{Et}_{4} \mathrm{Sn}$ at $20{ }^{\circ} \mathrm{C}$ leads to good yields of hept-1-ene or but-1-ene (from linoleic or linolenic esters, respectively), penta-1,4-diene, deca-1,4-diene, methyl dec-9-enoate and methyl trideca-9,12-dienoate, as illustrated for methyl linoleate in Eq. $13^{24}$. 


$$
\begin{gathered}
\mathrm{Me}\left(\mathrm{CH}_{2}\right)_{4} \mathrm{CH}=\mathrm{CHCH}_{2} \mathrm{CH}=\mathrm{CH}\left(\mathrm{CH}_{2}\right)_{7} \mathrm{COOMe}+ \\
\mathrm{CH}_{2}=\mathrm{CH}_{2} \rightleftharpoons \mathrm{CH}_{2}=\mathrm{CH}\left(\mathrm{CH}_{2}\right)_{4} \mathrm{Me}+ \\
\mathrm{CH}_{2}=\mathrm{CHCH}_{2} \mathrm{CH}=\mathrm{CH}_{2}+ \\
\mathrm{CH}_{2}=\mathrm{CHCH}_{2} \mathrm{CH}=\mathrm{CH}\left(\mathrm{CH}_{2}\right)_{4} \mathrm{Me}+ \\
\mathrm{CH}_{2}=\mathrm{CH}\left(\mathrm{CH}_{2}\right)_{7} \mathrm{COOMe}+ \\
\mathrm{CH}_{2}=\mathrm{CHCH}_{2} \mathrm{CH}=\mathrm{CH}\left(\mathrm{CH}_{2}\right)_{7} \mathrm{COOMe}
\end{gathered}
$$

A variety of unsaturated fatty oils may serve as easily obtainable and relatively cheap raw materials of this type. Thus, good results have also been obtained in the ethenolysis of methyl esters from olive oil and palm oil ${ }^{25}$.

\section{Catalysts}

Because of the potential industrial importance of the reaction, much effort has been devoted to the development of catalysts able to bring about the metathesis of unsaturated fatty acid esters. A problem is the deactivation of catalytic sites by the functional group resulting in turnover numbers which are much lower than those obtained for the metathesis of analogous simple olefins. Examples of catalyst systems which can withstand the negative effect of the polar group to a certain extent are given in the Table 1 .

\section{Homogeneous systems}

Undoubtedly the most active homogeneous catalyst systems are the well-defined metal alkylidene complexes synthesised in the laboratories of Schrock ${ }^{29,33,34}$ and Basset $^{32}$. Such systems are characterised by a metal (W, Mo or $\mathrm{Re}$ ) in its highest oxidation state containing in its co-ordinating sphere both alkylidene and bulky electron-withdrawing ligands (aryloxides, fluoroalkoxides, etc.); examples are the complexes I, II and III. The bulkiness of aryloxides ${ }^{32}$ and imido or alkylidyne ligands ${ }^{29,33,34}$ would prevent dimerization of these electron-deficient organometallic complexes and, to some extent, the co-ordination of the functional group to the metal atom ${ }^{35}$.

On the other hand, two-component catalyst systems, ma-

\begin{tabular}{|c|c|c|c|c|c|c|}
\hline Catalyst & Substrate $^{\mathrm{a}}$ & $\begin{array}{c}{[\text { Ester }] /} \\
{[\text { Metal atom] }}\end{array}$ & $\mathrm{T} /{ }^{\circ} \mathrm{C}$ & $\mathrm{t}^{\mathrm{b}} / \mathrm{h}$ & $\begin{array}{l}\text { turnover } \\
\text { number }\end{array}$ & Ref. \\
\hline \multicolumn{7}{|l|}{ Homogeneous systems } \\
\hline $\mathrm{WCl}_{6} / \mathrm{Me}_{4} \mathrm{Sn}$ & $\mathrm{MeOl}$ & 75 & 110 & 2 & 38 & 22 \\
\hline $\mathrm{WOCl}_{4} / \mathrm{Me}_{4} \mathrm{Sn}$ & $\mathrm{MeOl}$ & 50 & 70 & 6 & 25 & 26 \\
\hline $\mathrm{WOCl}_{4} / \mathrm{Cp}_{2} \mathrm{TiMe}_{2}$ & EtOl & 50 & 70 & 20 & 18 & 27 \\
\hline $\mathrm{W}\left(=\mathrm{CHCMe}_{3}\right) \mathrm{Np}(\mathrm{Cl})(\mathrm{OAr})_{2}\left(\mathrm{OR}_{2}\right)^{\mathrm{c}}$ & EtOl & 100 & 85 & 1 & 32 & 28 \\
\hline$[\mathrm{W}]=\mathrm{CHCMe}_{3}$ (see formula I) & $\mathrm{MeOl}$ & $200-300$ & 25 & $2-3$ & $100-150$ & 29 \\
\hline $\mathrm{W}(\mathrm{OAr})_{2} \mathrm{Cl}_{4} / \mathrm{R}_{4} \mathrm{Sn}$ or $\mathrm{Bu}_{4} \mathrm{~Pb}^{\mathrm{d}}$ & EtOl & 50 & 85 & 6 & 25 & 30 \\
\hline $\mathrm{WOCl}_{4} / \mathrm{DSCB}^{\mathrm{e}}$ & EtPe & 150 & 70 & 6 & 81 & 31 \\
\hline$[\mathrm{W}]=\mathrm{CHCMe}_{3}$ (see formula II) & EtOl & 500 & 25 & 1 & 250 & 32 \\
\hline$[\mathrm{Re}]=\mathrm{CHCMe}_{3}$ (see formula III) & $\mathrm{MeOl}$ & 100 & 20 & 6 & 50 & 33 \\
\hline $\mathrm{Mo}\left(=\mathrm{CHCMe}_{2} \mathrm{Ph}\right)(\mathrm{NAr})\left(\mathrm{ORF}_{6}\right)_{2}^{\mathrm{f}}$ & $\mathrm{MePe}$ & 1000 & 20 & 1 & 840 & 34 \\
\hline \multicolumn{7}{|l|}{ Heterogeneous systems } \\
\hline $\mathrm{Re}_{2} \mathrm{O}_{7} / \mathrm{Al}_{2} \mathrm{O}_{3} / \mathrm{Et}_{4} \mathrm{Sn}$ & $\mathrm{MeOl}$ & 60 & 20 & 2 & 3 & 8 \\
\hline $\mathrm{MoO}_{3} / \mathrm{Re}_{2} \mathrm{O}_{7} / \mathrm{Al}_{2} \mathrm{O}_{3} / \mathrm{Et}_{4} \mathrm{Sn}$ & $\mathrm{MeOl}$ & 60 & 20 & 2 & 30 & 8 \\
\hline $\mathrm{Re}_{2} \mathrm{O}_{7} / \mathrm{SiO}_{2}-\mathrm{Al}_{2} \mathrm{O}_{3} / \mathrm{Bu}_{4} \mathrm{Sn}$ & $\mathrm{MeOl}$ & 240 & $40-45$ & 3 & 120 & 23 \\
\hline $\mathrm{Re}_{2} \mathrm{O}_{7} / \mathrm{B}_{2} \mathrm{O}_{3} / \mathrm{SiO}_{2}-\mathrm{Al}_{2} \mathrm{O}_{3} / \mathrm{Bu}_{4} \mathrm{Sn}$ & MeUn & 350 & 50 & 13 & 348 & 21 \\
\hline $\mathrm{MoCl}_{5} / \mathrm{SiO}_{2} / \mathrm{R}_{4} \mathrm{Sn}$ & $\mathrm{EtOl}+$ dec-5-ene & 110 & 90 & 4 & 99 & 15 \\
\hline $\mathrm{MoO}_{3} / \mathrm{SiO}_{2} /(\mathrm{CO}, h v) /$ cyclopropane & EtOl & 250 & 50 & 0.17 & 125 & 16 \\
\hline $\mathrm{MoO}_{3} / \mathrm{SiO}_{2} /(\mathrm{CO}$, laser $) /$ cyclopropane & $\mathrm{MeOl}$ & 1250 & 40 & 3 & 500 & 23 \\
\hline
\end{tabular}
inly $\mathrm{WOCl}_{4}$ and $\mathrm{WCl}_{6}$ with a suitable cocatalyst (an alkylating agent such as $\mathrm{Me}_{4} \mathrm{Sn}$ ), have been widely employed on a laboratory scale. These are cheaper and easier to handle than the alkylidene complexes. In this sense, the use of

Table 1. Examples of catalyst systems for the metathesis of unsaturated esters.

${ }^{\mathrm{a}} \mathrm{MeOl}=$ methyl oleate $; \mathrm{EtOl}=$ ethyl oleate $; \mathrm{EtPe}=$ ethyl pentenoate $; \mathrm{MePe}=$ methyl pentenoate $; \mathrm{MeUn}=$ methyl undecenoate $;{ }^{\mathrm{b}} t=$ time to reach the highest conversion; ${ }^{\mathrm{c}} \mathrm{Ar}=\mathrm{C}_{6} \mathrm{H}_{3}-(\mathrm{Ph})_{2}-2,6 ; \mathrm{Np}=\mathrm{CH}_{2} \mathrm{CMe}_{3} ; \mathrm{R}=\mathrm{Et}, \quad i$ - $\mathrm{Pr} ;{ }^{\mathrm{d}} \mathrm{Ar}=\mathrm{C}_{6} \mathrm{H}_{3}-(\mathrm{Cl})_{2}-2,6$ or $\mathrm{C}_{6} \mathrm{H}_{3}-(\mathrm{Br})_{2}-2,6 ;{ }^{\mathrm{e}} \mathrm{DSCB}=$ 1,1,3,3-(Me) $)_{4}-1,3-$ disilacyclobutane; ${ }^{\mathrm{f}} \mathrm{Ar}=\mathrm{C}_{6} \mathrm{H}_{3}-(i-\mathrm{Pr})_{2}-2,6 ; \mathrm{RF}_{6}=\mathrm{CMe}\left(\mathrm{CF}_{3}\right)_{2}$. 


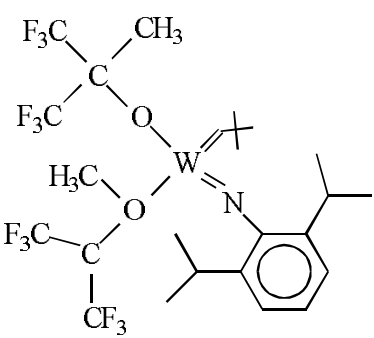

I

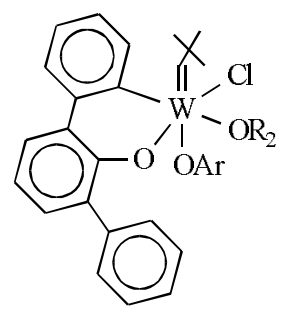

II

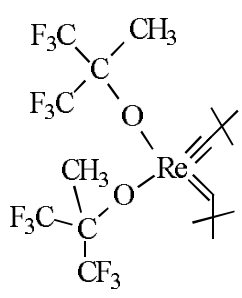

III
$\mathrm{W}(\mathrm{OAr})_{2} \mathrm{Cl}_{4}$ has the advantage of allowing its manipulation under air ${ }^{30}$. The role of the cocatalyst would be a double alkylation of the metal centre, followed by an $\alpha$-H-elimination leading to the formation of an alkylidene ligand. A butylidene ligand has indeed been observed during in situ ${ }^{1} \mathrm{H}-\mathrm{NMR}$ studies of the system $\mathrm{W}\left(\mathrm{OC}_{6} \mathrm{H}_{3}-\mathrm{Ph}_{2}-2,6\right)_{2} \mathrm{Cl}_{4} / \mathrm{Bu}_{4} \mathrm{~Pb}^{30}$.

\section{Heterogeneous systems}

Heterogeneous catalysts seem more suitable for industrial applications, because they are more favourable with respect to the separation of the catalyst from the reaction products, catalyst regeneration and application in continuous processes. The most active systems are based on rhenium or molybdenum oxides. They are usually prepared by impregnation of the support with an aqueous solution of the ammonium salt of the transition metal. After drying in air at $110^{\circ} \mathrm{C}$ and calcination at the desired temperature (usually between 500 and $550{ }^{\circ} \mathrm{C}$ ), the catalysts are commonly formulated as $\mathrm{Re}_{2} \mathrm{O}_{7} /$ support or $\mathrm{MoO}_{3}$ /support. However, in order to be able to bring about metathesis of functionalized olefins, these catalysts need either the addition of a promoter as cocatalyst $\left(\mathrm{Re}_{2} \mathrm{O}_{7} /\right.$ support $+\mathrm{R}_{4} \mathrm{Sn}$ or $\left.\mathrm{R}_{4} \mathrm{~Pb}\right)$ or to undergo a special activation procedure $\left(\mathrm{MoO}_{3} /\right.$ support $)$. Several parameters can affect the performance of these catalytic systems, such as (i) the transition metal loading; (ii) the kind of support; (iii) the calcination procedure; (iv) the transition metal/cocatalyst molar ratio; etc. The table presents the best performances reported for each system. The very high selectivity $(>97 \%)$ encountered in the metathesis of fatty acid esters might be due to the complexation of the ester group to the Brönsted acid sites on the support, preventing side reactions such as double bond shift.

\section{Rhenium Catalysts}

$\mathrm{Re}_{2} \mathrm{O}_{7} / \mathrm{Al}_{2} \mathrm{O}_{3} / \mathrm{Me}_{4} \mathrm{Sn}$ was the first heterogeneous catalyst system found to be effective for the metathesis of olefinic esters ${ }^{36}$. The catalytic performance of this system has since been improved in several ways by (i) the incorporation of a third metal oxide such as $\mathrm{V}_{2} \mathrm{O}_{5}, \mathrm{MoO}_{3}$ or $\mathrm{WO}_{3}{ }^{37,38}$; (ii) the use of a modified support, e.g. $\mathrm{SiO}_{2}-\mathrm{Al}_{2} \mathrm{O}_{3}{ }^{39}$, $\mathrm{Al}_{2} \mathrm{O}_{3}-\mathrm{B}_{2} \mathrm{O}_{3}{ }^{40}$, phosphated alumina ${ }^{41}$ or borated sili- ca-alumina $^{21}$; (iii) the use of another promoter, such as $\mathrm{Bu}_{4} \mathrm{Sn}, \mathrm{Et}_{4} \mathrm{Sn}$ or $\mathrm{R}_{4} \mathrm{~Pb}^{8}$.

\section{Structure $x$ catalytic activity}

Many spectroscopic studies have been carried out in order to characterise the surface structure of Re2O7/Al2O3 catalysts 42 . The system is generally described as a monolayer catalyst; the rhenium oxide species which are catalyst site precursors are bonded to the alumina surface as monomeric species, presenting a $\mathrm{C}_{3 \mathrm{v}}$ symmetry. The structure of the rhenium oxide phase present on $\mathrm{SiO}_{2}-\mathrm{Al}_{2} \mathrm{O}_{3}$ has been studied less. However, at least up to a $3 \mathrm{wt} \% \mathrm{Re}_{2} \mathrm{O}_{7}$ loading, the rhenium oxide supported on $\mathrm{SiO}_{2}-\mathrm{Al}_{2} \mathrm{O}_{3}$ has predominantly a monomeric structure; at higher loadings it might also be present as three-dimensional clusters ${ }^{43}$.

The catalytic activity of $\mathrm{Re} 2 \mathrm{O} 7 / \mathrm{Al} 2 \mathrm{O} 3$ increases with the rhenium loading. A positive correlation between the catalytic activity and the surface acidity (mainly the Brönsted acidity) of such systems has been observed ${ }^{44,45}$. The activity of $\mathrm{Re}_{2} \mathrm{O}_{7} / \mathrm{Al}_{2} \mathrm{O}_{3}$ catalysts can be explained on the basis of the activity of the surface $\mathrm{ReO}_{4}$ groups which have reacted with Lewis acid sites and with the different aluminium-bonded $\mathrm{OH}$ groups during the preparation of the catalyst ${ }^{41}$. The most active sites arise from the reaction between $\mathrm{ReO}_{4}{ }^{-}$ions and the most acidic $\mathrm{OH}$ groups on the alumina surface to form Al-bonded $\mathrm{ReO}_{4}$ species. Such reactions are favoured only after the basic and neutral $\mathrm{OH}$ groups have reacted to some extent.

On the other hand, when $\mathrm{SiO}_{2}-\mathrm{Al}_{2} \mathrm{O}_{3}$ is used as the support, the specific catalytic activity decreases as the rhenium loading is increased ${ }^{46}$. By analogy with the explanation given above for $\mathrm{Al}_{2} \mathrm{O}_{3}$ it is thought that there are two types of hydroxyl groups on $\mathrm{SiO}_{2}-\mathrm{Al}_{2} \mathrm{O}_{3}$ : hydroxyl groups attached to a $\mathrm{Si}$ atom and bridging hydroxyl groups attached to both a $\mathrm{Si}$ and an $\mathrm{Al}$ atom. The reaction of $\mathrm{ReO}_{4}{ }^{-}$ions with the bridging hydroxyl groups would result in electropositive rhenium centres $\left(\mathrm{ReO}_{4}{ }^{-}\right.$tetrahedra), the active sites. Thus, higher rhenium loadings would favour the formation of inactive sites of the type $\Leftarrow \mathrm{Si}-\mathrm{O}-\mathrm{ReO}_{3}$, as it is known that $\mathrm{Re}_{2} \mathrm{O}_{7} / \mathrm{SiO}_{2}$ has no activity in olefin metathesis ${ }^{47}$. It should be pointed out, however, that a great difficulty in the characterisation of 
these systems lies in the fact that only $\mathrm{ca} .1 \%$ of the rhenium sites are active in metathesis ${ }^{48,49}$.

\section{Role of the promoter}

Although rhenium-based systems are only active for the metathesis of functionalized olefins when promoted with an alkyltin or alkyllead compound, the role of the latter is still not well understood. Reduction of the rhenium atom, modification of the active site (by addition of a tin ligand) and formation of the initiating metal-alkylidene species (via a double alkylation followed by an $\alpha-\mathrm{H}$-abstraction) have been postulated as promotion mechanisms ${ }^{50}$. However, only a few studies have been carried out concerning the nature of the interaction between the tin compound and the surface rhenium species ${ }^{51-55}$. Evidence for the presence of Re-O-Sn bonds comes from Raman spectroscopic studies of $\mathrm{Re}_{2} \mathrm{O}_{7} / \mathrm{Al}_{2} \mathrm{O}_{3} / \mathrm{Me}_{4} \mathrm{Sn}^{53}$. Based on ${ }^{119} \mathrm{Sn}$ Mössbauer and ${ }^{13} \mathrm{C}$ and ${ }^{119} \mathrm{Sn}$ MAS NMR experiments with $\mathrm{Re}_{2} \mathrm{O}_{7} / \mathrm{SiO}_{2}-\mathrm{Al}_{2} \mathrm{O}_{3} / \mathrm{R}_{4} \mathrm{Sn}$, reactions as depicted in Scheme 2 have been proposed ${ }^{54}$. The $\mathrm{R}$ ligand on species A might still undergo an electrophilic attack from a remaining $\mathrm{OH}^{-}$group from the surface with release of an alkane. If a double alkylation involving only one rhenium site takes place, a coordinatively saturated species, $\mathbf{B}$, would be formed. This species might undergo an $\alpha-\mathrm{H}$-abstraction, spontaneous or surface-induced, leading to a rhenium-alkylidene species, $\mathbf{C}$. Although an alkylidene ligand in the rhenium co-ordination sphere could not be spectroscopically identified, chemical reactivity suggests its presence in minor amounts. While species $\mathbf{A}$ would predominate for $\mathrm{Re}_{2} \mathrm{O}_{7} / \mathrm{SiO}_{2}-\mathrm{Al}_{2} \mathrm{O}_{3} / \mathrm{R}_{4} \mathrm{Sn}$ systems, in particular when $\mathrm{R}=\mathrm{Et}$, for $\mathrm{Re}_{2} \mathrm{O}_{7} / \mathrm{Al}_{2} \mathrm{O}_{3} / \mathrm{Bu}_{4} \mathrm{Sn}$ there would only be species $\mathbf{C}$ or $\mathbf{D}^{55}$. Taking into account that (i) for $\mathrm{Re}_{2} \mathrm{O}_{7} / \mathrm{SiO}_{2}-\mathrm{Al}_{2} \mathrm{O}_{3} / \mathrm{R}_{4} \mathrm{Sn}$ systems the highest catalytic activity per rhenium atom is obtained when $\mathrm{R}=\mathrm{Et}^{8}$, for which species $\mathbf{A}$ appears in higher concentration than for
$\mathrm{R}=\mathrm{Bu}$ or $\mathrm{Me}$, and (ii) species $\mathbf{C}$ and/or $\mathbf{D}$ are the only ones present on the surface of $\mathrm{Re}_{2} \mathrm{O}_{7} / \mathrm{Al}_{2} \mathrm{O}_{3} / \mathrm{Bu}_{4} \mathrm{Sn}$, which is less active, it seems that with these systems the presence of a pre-formed alkylidene ligand may not be a prerequisite for metathesis to take place.

\section{Organometallic models of active sites}

Since $\mathrm{Re}_{2} \mathrm{O}_{7}$ reacts with $\mathrm{Me}_{4} \mathrm{Sn}$ to form $\mathrm{CH}_{3} \mathrm{ReO}_{3}{ }^{56}$, it has been suggested that the latter complex is an intermediate in the heterogeneous system. In solution $\mathrm{CH}_{3} \mathrm{ReO}_{3}$ is active for the metathesis of cyclic and acyclic olefins, but only in the presence of both a Lewis acid and an alkylating agent. On the other hand, when supported on $\mathrm{Al}_{2} \mathrm{O}_{3}, \mathrm{SiO}_{2}-\mathrm{Al}_{2} \mathrm{O}_{3}$ or $\mathrm{Nb}_{2} \mathrm{O}_{5}$, it becomes an efficient metathesis catalyst - even for functionalized olefins - without a promoter ${ }^{57,58}$. Although ${ }^{13} \mathrm{C}$-NMR studies show that the organic ligand remains attached to the rhenium atom after interaction between $\mathrm{CH}_{3} \mathrm{ReO}_{3}$ and $\mathrm{Nb}_{2} \mathrm{O}_{5}{ }^{58}$, exchange reactions with a symmetrical olefin using a ${ }^{13} \mathrm{C}$ labelled sample showed that the first metal-alkylidene species does not arise from the methyl group, but from the olefin itself ${ }^{59}$. The main role of the support would be to increase the Lewis acidity of the rhenium centre.

Another approach to prepare surface-anchored alkylidene species is based on the fact that in solution Schrock-type tungsten alkylidene complexes (which are expected to have the same chemical behaviour as their rhenium analogues) can be synthesised from the corresponding alkylidyne complexes via protonation by Brönsted acids ${ }^{60}$. Thus, Schrock-type tungsten alkylidyne complexes, precursors of the homogeneous catalysts I and II, have been reacted with the surface of $\mathrm{SiO}_{2}{ }^{61,62}, \mathrm{Nb}_{2} \mathrm{O}_{5}, \mathrm{Al}_{2} \mathrm{O}_{3}$ and $\mathrm{SiO}_{2}-\mathrm{Al}_{2} \mathrm{O}_{3}{ }^{63}$, respectively, leading in all cases to very active catalysts for the metathesis of simple olefins. Chemical and spectroscopic studies of these systems point to the presence of several

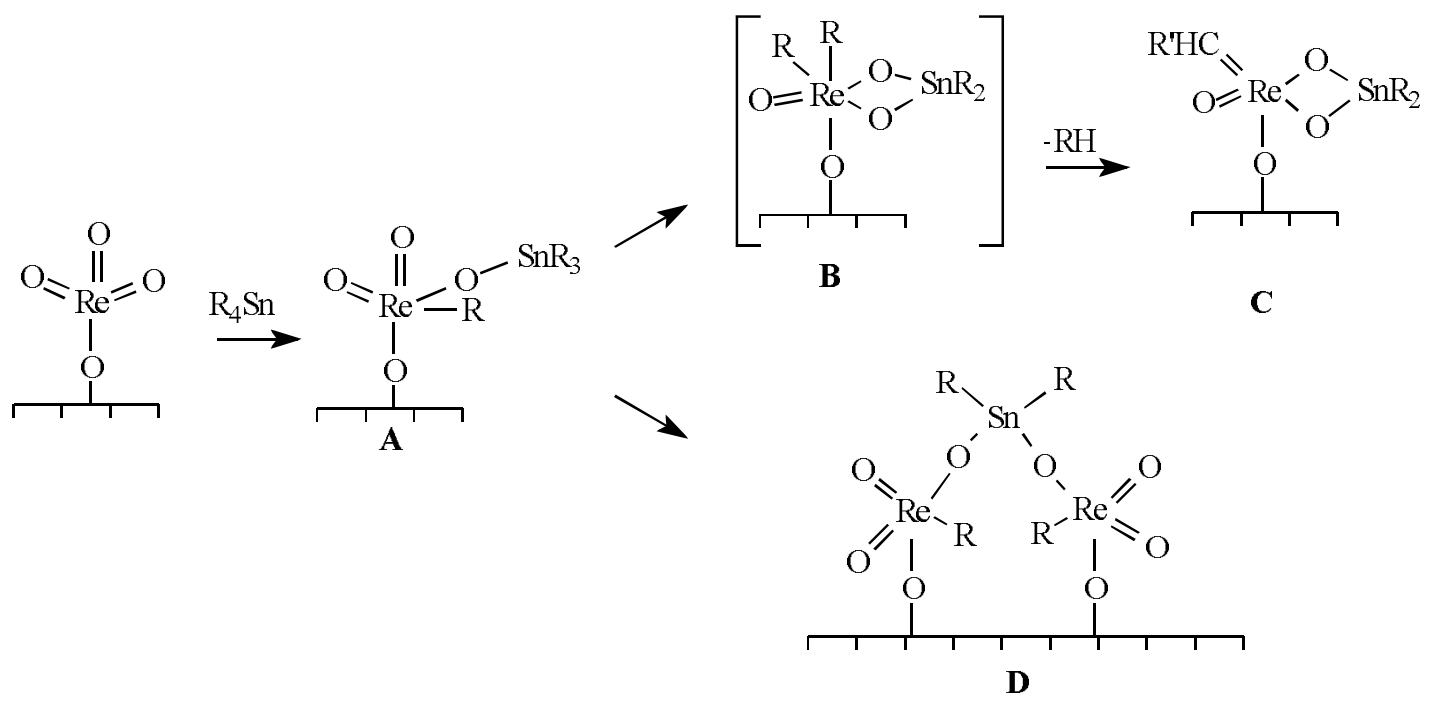

Scheme 2. 
surface species, at least one of them bearing an alkylidene ligand $^{63}$. However, metathetical exchange experiments suggest that the most active systems are those that can react with olefins and form the initiating metal-alkylidene species via a $\pi$-allyl mechanism ${ }^{62,63}$. It has been proposed that surface Lewis acid sites induce the formation of a tetracoordinated cationic neopentylidenetungsten(VI) complex (Scheme 3), which might well be the precursor of the most active species due to its high electronic and coordinative unsaturation ${ }^{63}$. The presence of such a species could account for both the high isomerization (through double-bond migration) observed for terminal olefins and the lack of catalytic activity of these heterogeneous systems towards functionalized olefins ${ }^{64}$.

All results discussed above show that surface organometallic approaches to the synthesis of well-defined heterogeneous metathesis catalysts have so far failed to provide a good picture of the actual active site, the homogeneous systems being not an adequate model for their heterogeneous counterparts.

\section{Catalyst deactivation and regeneration}

The activity of any catalytic system in the metathesis of olefinic esters is unavoidably limited by the presence of the functional group ${ }^{23}$. Besides an intrinsic deactivation mechanism (reductive elimination of the metallacyclobutane intermediate ${ }^{65}$, a Wittig-type reaction between the carbonyl group and the metal-alkylidene may also be responsible for a decrease in catalytic activity. These systems are also air sensitive. ${ }^{119} \mathrm{Sn}$ Mössbauer spectroscopic studies of $\mathrm{Re}_{2} \mathrm{O}_{7} / \mathrm{SiO}_{2}-\mathrm{Al}_{2} \mathrm{O}_{3} / \mathrm{R}_{4} \mathrm{Sn}$ systems suggest that air exposure does not cause hydrolysis of Sn-O-Re bonds; such bonds might, however, be weakened owing to a change in the co-ordination sphere of the rhenium atom ${ }^{54}$.

After deactivation, the catalyst can be regenerated many times via calcination followed by addition of another amount of the promoter. However, there is a limit to the number of times the catalyst can be regenerated in this way ${ }^{66} .{ }^{119} \mathrm{Sn}$ Mössbauer spectroscopic studies revealed after calcination the formation of both an $\mathrm{SnO}_{2}$ phase and a polymeric ionic Sn(IV) species, probably bonded to the rheni-

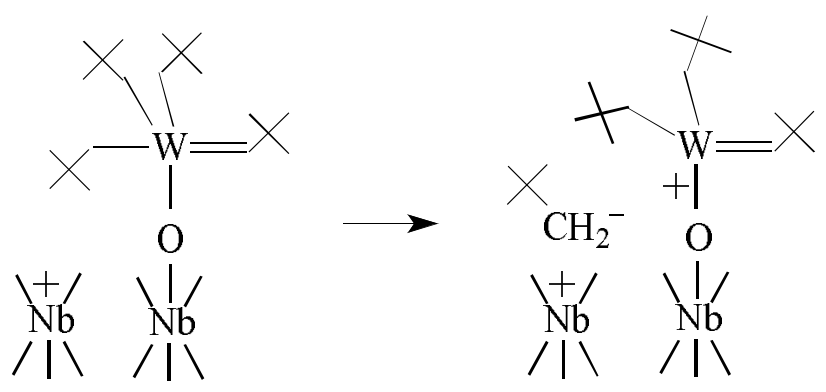

Scheme 3. $u^{54,55}$, which eventually would prevent the formation of new active sites.

\section{Molybdenum Catalyst}

Only two of the many Mo-based heterogeneous metathesis catalyst systems have been reported to bring about the metathesis of functionalized olefins, viz. $\mathrm{MoCl}_{5} / \mathrm{SiO}_{2} / \mathrm{R}_{4} \mathrm{Sn}^{15}$ and $\mathrm{Mo} / \mathrm{SiO}_{2}$, photoreduced in $\mathrm{CO}$ at room temperature and subsequently activated with cyclopropane. The latter system has been systematically studied and will be discussed here.

\section{Photoreduced molybdenum catalysts}

Photoreduction of calcined $1 \mathrm{wt} \% \mathrm{MoO}_{3} / \mathrm{SiO}_{2}$ with a $\mathrm{Hg}$ lamp in a CO atmosphere leads mainly to Mo(IV) ions ${ }^{68,69}$. The resulting system is active for the metathesis of propene. Treatment of this system with cyclopropane results in a sharp increase of its specific activity ${ }^{70}$. Moreover, the catalyst becomes active for the metathesis of olefinic esters ${ }^{16}$. From IR and UV/vis spectroscopic studies it was concluded that a molybdenacyclobutane intermediate is formed, which decomposes into molybdenum-alkylidene and Mo(IV)$\pi$-olefin complexes; Scheme $4^{70-72}$. The molybdenum-alkylidene complexes were characterised by an absorption band at $450-480 \mathrm{~nm}$ in the electronic spectrum ${ }^{70}$. They proved to be thermally stable up to $430^{\circ} \mathrm{C}$ and oxygen resistant at room temperature. Interestingly, the proposed $[\mathrm{Mo}]=\mathrm{CH}_{2}$ species does not undergo a Wittig-type reaction with acetone ${ }^{70}$, which is characteristic of Schrock-type alkylidene complexes.

An alternative activation procedure, consisting of photoreduction of $\mathrm{MoO}_{3} / \mathrm{SiO}_{2}$ in $\mathrm{CO}$ with a laser beam of $308 \mathrm{~nm}$ instead of a Hg lamp, followed by cyclopropane treatment leads to a catalyst of even higher activity ${ }^{23,67}$.

\section{Catalyst deactivation}

Studies concerning the stability of the catalyst during continuous metathesis of propene showed a loss of activity independent of the propene flow rate, suggesting an intrinsic deactivation mechanism ${ }^{73}$. Due to the high stability of both $[\mathrm{Mo}]=\mathrm{CH}_{2}$ and $[\mathrm{Mo}]=\mathrm{CHCH}_{3}$, the deactivation of the catalyst is assigned to isomerization of the intermediate metallacyclobutane complexes, leading to inactive $\pi$-complexes, in a way analogous to that depicted in Scheme 4. This hypothesis is supported by in situ UV/vis spectroscopic studies ${ }^{73}$.

\section{Perspectives}

Despite its considerable potential, the metathesis of unsaturated fatty oils and their derivatives has not yet been adopted by the chemical industry. The activity of the catalysts is decreased by the functional group and thus catalyst costs are high, because high catalyst concentrations are required. Besides the intrinsic deactivation reactions, catalyst 


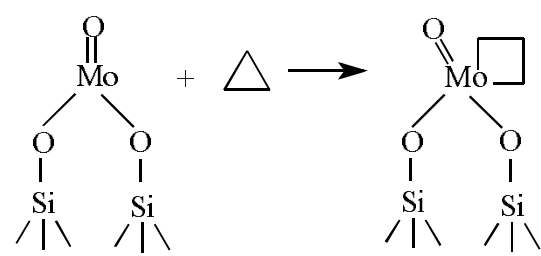

Scheme 4.

deactivation might in practice also take place due to impurities in the substrate, complexation of the functional group to the active site or adsorption of product molecules (when using a solid catalyst), which can block active sites.

The question of activity concerns not only the turnover number that can be attained, but also the reaction rate (in other words, how long the reaction takes to reach an acceptable conversion). For the well-defined homogeneous catalyst complexes a considerable amount of time and money may be expended in just the catalyst preparation alone, which means that from an industrial point of view they are very expensi$\mathrm{ve}^{74}$. Therefore, in view of the present knowledge, regenerable heterogeneous catalysts are superior.

Although rhenium is a precious metal, rhenium-based catalysts are to be preferred over molybdenum ones because their activation is much simpler and regenerability is much better. After the catalyst has deactivated, the question is not only whether, but also how many times it can be regenerated. Heterogeneous rhenium oxide catalysts can be regenerated many times without any loss of activity, while the rhenium can be recovered from these catalysts after total deactivation. Moreover, metathesis can be carried out with these catalysts under mild reaction conditions and with high selectivity. This means that there are favourable prospects for its application in oleochemistry.

\section{References}

1. Kaufman, A.J.; Ruebusch, R.J. In Proceedings World Conference on Oleochemicals (Kuala Lumpur, Malaysia 1990); Applewhite, T.H., Ed.; American Oil Chemists' Society; Champaign, IL, 1991, p 10; Hirsinger, F. Oléagineux 1986, 41, 345.
2. Ivin, K.J.; Mol, J.C. Olefin Metathesis and Metathesis Polymerization; Academic Press; London, 1997.

3. van Dam, P.B.; Mittelmeijer, M.C.; Boelhouwer, C. J. Chem. Soc., Chem. Commun. 1972, 1221.

4. Choo, Y-M.; Ooi, K-E.; Ooi, I-H. J. Am. Oil Chem. Soc. 1994, 71, 911.

5. Tsuji, J.; Hashiguchi, S. Tetrahedron Lett. 1980, 21, 2955.

6. van Thiel, J.M.; Boelhouwer, C. Farbe Lack 1974, 80, 1928.

7. Choo, Y-M.; Ooi, K-E., Ooi, I-H.; Tan, D.D.H. J. Am. Oil Chem. Soc. 1996, 73, 333.

8. Mol, J.C. J. Mol. Catal. 1991, 65,145.

9. Plugge, M.F.C.; Mol, J.C. Synlett 1991, 507.

10. Verkuijlen, E.; Boelhouwer, C. Fette, Seifen, Anstrichm. 1976, 78, 444.

11. Verkuijlen, E.; Dirks, R.J.; Boelhouwer, C. Recl. Trav. Chim. Pays-Bas 1977, 96, M86.

12. Bosma, R.H.A.; van den Aardweg, G.C.N.; Mol, J.C. J. Organomet. Chem. 1983, 255, 159.

13. Warwel, S.; Deckers, A. Tens. Surf. Det. 1989, 26, 252.

14. Penninger, J.; Biermann, M.; Krouse, H-J. Fette, Seifen, Anstrichm. 1983, 85, 239.

15. Bykov, V.I.; Butenko, T.A.; Finkel'shtein, E.Sh. Izv. Akad. Nauk SSSR, Ser. Khim. 1988, 37, 1580.

16. Berezin, M.Yu.; Ignatov, V.M.; Belov, P.S.; Elev, I.V.; Shelimov, B.N.; Kazansky, V.B. Kinet. Katal. 1991, 32, 379.

17. Boelhouwer, C.; Mol, J.C. Prog. Lipid Res. 1985, 24, 243.

18. Villemin, D. Tetrahedron Lett. 1983, 24, 2855.

19. Bosma, R.H.A.; van den Aardweg, F.; Mol, J.C. J. Chem. Soc., Chem. Commun. 1981, 1132.

20. Sibeijn, M.; Mol, J.C. J. Mol. Catal. 1992, 76, 345. 
21. Warwel, S.; Jägers, H-G.; Thomas, S. Fat Sci. Technol. 1992, 94, 323.

22. van Dam, P.B.; Mittelmeijer, M.C.; Boelhouwer, C. J. Am. Oil Chem. Soc. 1974, 51, 389.

23. Mol, J.C. J. Mol. Catal. 1994, 90, 185.

24. Bosma, R.H.A. Ph. D. Thesis, Universiteit van Amsterdam, The Netherlands, 1983.

25. Mandelli, D.; Jannini, M.J.D.M.; Buffon, R.; Schuchardt, U. J. Am. Oil Chem. Soc. 1996, 73, 229.

26. Verkuijlen, E. J. Mol. Catal. 1980, 8, 107.

27. Tsuji, J.; Hashiguchi, S. J. Organomet. Chem. 1981, 218 , 69.

28. Quignard, F.; Leconte, M.; Basset, J.-M. J. Chem. Soc., Chem. Commun. 1985, 1816.

29. Schaverien, C J.; Dewan, J.C.; Schrock, R.R. J. Am. Chem. Soc. 1986, 108, 2771.

30. Quignard, F.; Leconte, M.; Basset, J.-M. J. Mol. Catal. 1986, 36, 13.

31. Bespalova, N.B.; Bovina, M.A. J. Mol. Catal. 1992, 76, 181.

32. Couturier, J.-L.; Paillet, C.; Leconte, M.; Basset, J.-M.; Weiss, K. Angew. Chem., Int. Ed. Engl. 1992, 31, 628.

33. Toreki, R.; Vaughan, G.A.; Schrock, R.R.; Davis, W.M. J. Am. Chem. Soc. 1993, 115, 127.

34. Fox, H.H.; Schrock, R.R.; O’Dell, R. Organometallics, 1994, 13, 635.

35. Lefebvre,F.; Leconte, M.; Pagano, S.; Mutch, A.; Basset, J.-M. Polyhedron 1995, 14, 3209.

36. Verkuijlen, E.; Kapteijn, F.; Mol, J.C.; Boelhouwer, C. J. Chem. Soc., Chem. Commun. 1977, 198.

37. Xu, X.; Imhoff, P.; van den Aardweg, G.C.N.; Mol, J.C. J. Chem. Soc., Chem. Commun. 1985, 273.

38. Nakamura, R.; Echigoya, E. Recl. Trav. Chim. Pays-Bas 1977, 96, M31.

39. Xu, X.; Mol, J.C. J. Chem. Soc., Chem. Commun. 1985, 631.

40. Xu, X.; Boelhouwer, C.; Benecke, J.I.; Vonk, D.; Mol, J.C. J. Chem. Soc., Faraday Trans. 1, 1986, 82, 1945.

41. Sibeijn, M.; Spronk, R.; van Veen, J.A.R.; Mol, J.C. Catal. Lett. 1991, 8, 201.

42. Reference 2, p. 36.

43. Spronk, R.; Mol, J.C. In New Frontiers in Catalysis; Guczi, L. et al., Ed.; Elsevier, Amsterdam, 1993, p. 2071.

44. Ellison, A.; Coverdale, A.K.; Dearing, P.F. Appl. Catal. 1983, 8, 109.

45. Xu, X.; Mol, J.C.; Boelhouwer, C. J. Chem. Soc., Faraday Trans. 1, 1986, 82, 2707.

46. Sibeijn, M.; Mol, J.C. Appl. Catal. 1991, 67, 279.

47. Mol, J.C.; Andreini, A. J. Mol. Catal. 1988, 46, 151.

48. Kapteijn, F.; Bredt, L.H.G.; Homburg, E.; Mol, J.C. Ind. Eng. Chem., Prod. Res. Dev. 1981, 20, 457.

49. Chauvin, Y.; Commereuc, D. J. Chem. Soc., Chem. Commun. 1992, 462.
50. Mol, J.C. In Olefin Metathesis and Polymerization Catalysts; Imamoglu, Y.; Zümreoglu-Karan, B.; Amass, A.J., Ed.; Kluwer, Dordrecht, 1990, p. 247.

51. Maksimov, Yu.V.; Kushnerev, M.Ya.; Dumesic, J.A.; Nechitailo, A.E.; Fridman, R.A. J. Catal. 1976, 45, 114.

52. Xu, X.; Andreini, A.; Mol, J.C. J. Mol. Catal. 1985, 28, 133.

53. Williams, K.P.J.; Harrison, K. J. Chem. Soc., Faraday Trans. 1990, 86, 1603.

54. Buffon, R.; Schuchardt, U.; Abras, A. J. Chem. Soc., Faraday Trans. 1995, 91, 3511.

55. Buffon, R.; Jannini, M.J.D.M.; Abras, A. J. Mol. Catal. 1997, 115, 173.

56. Herrmann, W.A.; Kuchler, J.G.; Felixberger, J.K.; Herdtweck, E.; Wagner, W. Angew. Chem., Int. Ed. Engl. 1988, 27, 394.

57. Herrmann, W.A.; Wagner, W.; Flessner, U.N.; Volkhardt, U.; Komber, H. Angew. Chem., Int. Ed. Engl. 1991, 30, 1636.

58. Buffon, R.; Auroux, A.; Lefebvre, F.; Leconte, M.; Choplin, A.; Basset, J.-M.; Herrmann, W.A. J. Mol. Catal. 1992, 76, 287.

59. Buffon, R.; Choplin, A.; Leconte, M.; Basset, J.-M.; Touroude, R.; Herrmann, W.A. J. Mol. Catal. 1992, 72, L7.

60. Freudenberger, J.H.; Schrock, R.R. Organometallics 1985, 4, 1937.

61. Weiss, K.; Lössel, G. Angew. Chem., Int. Ed. Engl. 1989, 28,62 .

62. Buffon, R.; Leconte, M.; Choplin, A.; Basset, J.-M. J. Chem. Soc., Chem. Commun. 1993, 361.

63. Buffon, R.; Leconte, M.; Choplin, A.; Basset, J.-M. J. Chem. Soc., Dalton Trans. 1994, 1723.

64. Buffon, R. Ph. D. Thesis, Université Claude-Bernard, France, 1992.

65. Spronk, R.; Andreini, A.; Mol, J.C. J. Mol. Catal. 1991, 65, 219.

66. Spronk, R.; Mol, J.C. Appl. Catal. 1991, 76, 143.

67. Mol, J.C. Catal. Lett. 1994, 23, 113.

68. Pershin, A.N.; Shelimov, B.N.; Kazansky, V.B. J. Catal. 1980, 64, 426.

69. Shelimov, B.N.; Elev, I.V.; Kazansky, V.B. J. Catal. 1986, 98, 70 .

70. Shelimov, B.N.; Elev, I.V.; Kazansky, V.B. J. Mol. Catal. 1988, 46, 187.

71. Vikulov, K.A.; Elev, I.V.; Shelimov, B.N.; Kazansky, V.B. J. Mol. Catal. 1989, 55, 126.

72. Vikulov, K.A.; Shelimov, B.N.; Kazansky, V.B. J. Mol. Catal. 1991, 65, 393.

73. Vikulov, K.A.; Shelimov, B.N.; Kazansky, V.B.; Mol, J.C. J. Mol. Catal. 1994, 90, 61.

74. Streck, R. J. Mol. Catal. 1992, 76, 359. 